\title{
EKONOMIA W DOBIE FINANSYZACJI GOSPODARKI
}

\section{UWAGI WSTĘPNE}

Pod koniec pierwszej dekady XXI w. wraz z początkiem tego, co określane jest niekiedy mianem największego kryzysu od czasu Wielkiego Kryzysu, uległa znacznemu ożywieniu dyskusja na temat kondycji nauk ekonomicznych, a zwłaszcza ekonomii w rozumieniu nauki odkrywającej i tworzącej teoretyczne podstawy polityki makroekonomicznej. Spektrum poglądów i stanowisk prezentowanych w ramach tej dyskusji ograniczone jest dwoma ekstremami. Jedno tworza opinie, które ocierają się, czy wręcz mogą być potraktowane jako wyraz współczesnego antyekonomizmu¹. Ta, tak stara jak sama ekonomia, idea sprowadza się do negacji użyteczności i naukowości ekonomii, a nawet oskarżania jej (a w zasadzie nie tyle samej ekonomii, ile ekonomistów) o przyczynianie się, przez lansowanie niesłusznych koncepcji, do powstawania czy narastania różnych negatywnych zjawisk społecznych. Współczesny antyekonomizm rzadko przyjmuje postać skrajna - prowadząca do negowania naukowego statusu ekonomii. Współczesny antyekonomizm raczej wyraża się $\mathrm{w}$ kwestionowaniu pewnego sposobu postrzegania i analizowania zjawisk gospodarczych, typowego zwłaszcza dla ekonomii głównego nurtu. Reprezentowany jest nie tylko przez osoby spoza środowiska ekonomicznego, lecz także przez niektórych ekonomistów, a zwłaszcza tych związanych z najbardziej radykalnymi ogniwami ekonomii alternatywnej².

* Prof. dr hab., Uniwersytet Ekonomiczny w Poznaniu, Katedra Teorii i Historii Ekonomii. Od 1 lutego 2012 r. podsekretarz stanu, a od 24 stycznia 2014 r. sekretarz stanu w Ministerstwie Nauki i Szkolnictwa Wyższego. Wszystkie zawarte w opracowaniu uwagi odzwierciedlają punkt widzenia autora i nie stanowia wyrazu stanowiska instytucji, w których jest zatrudniony. Opracowanie zostało oparte na tekście referatu przygotowanego na Kongres Ekonomistów zorganizowany przez Polskie Towarzystwo Ekonomiczne w Warszawie w listopadzie 2013 r. Referat będzie opublikowany na łamach „Ekonomisty” 2014, nr 2.

${ }^{1}$ Początki antyekonomizmu można wiązać zwłaszcza z osobą dziewiętnastowiecznego angielskiego historyka Thomasa Carlyle’a, który ekonomię określił mianem ponurej nauki, w przeciwieństwie do tzw. nauki radosnej, który to termin kojarzono z wiedzą przyczyniającą się do wzbogacenia życia. O współczesnym antyekonomizmie pisze m.in. Andrzej Wojtyna w artykule Wspótczesna ekonomia - kontynuacja czy poszukiwanie nowego paradygmatu?, „Ekonomista” 2008, nr 1 .

${ }^{2}$ Wyrazem takich bardzo radykalnych poglądów jest książka pod znamiennym tytułem Crisis in Economics, red. E. Fullbrock, Windpfert Verlaqsqes, 2003. Przy okazji należy jednak zauważyć, że odwoływanie się do idei kryzysu w ekonomii ma swoją całkiem długą historię i ostatnie lata nie 
Drugie ekstremum w dyskusjach o kondycji ekonomii wiąże się z poglądami, które nie tylko świadczą o ekonomicznym imperializmie kojarzonym z rozszerzaniem analizy ekonomicznej na inne obszary życia społecznego niż te, które mieszczą się w sferze gospodarczej, oraz z włączaniem narzędzi analizy ekonomicznej do arsenału badawczego innych nauk społecznych, ale mogą być uznane za wyraz triumfalizmu. Ekonomiczny triumfalizm to, w interpretacji autora, postrzeganie ekonomii jako nauki bezdyskusyjnej w swych ustaleniach, a zarazem przypisywanie jej wyższości w stosunku do innych nauk społecznych ${ }^{3}$. Ekonomiczny triumfalizm to także wiara w koniec historii na niwie ekonomicznej, zwiąany z upadkiem systemu gospodarek centralnie zarządzanych i powszechnością rozwiązań rynkowych, czego wyrazem jest m.in. idea określana w skrócie jako TINA (There is no alternative).

Prezentowane opracowanie stanowi swoiste résumé poglądów i zainteresowań autora zarówno pewnymi aspektami kryzysu i przeobrażeń współczesnej gospodarki rynkowej, które znajdują wyraz w idei finansyzacji gospodarki, jak i rozwojem ekonomii jako nauki.

\section{FINANSYZACJA GOSPODARKI ${ }^{4}$}

Słowo finansyzacja jest odpowiednikiem angielskiego financialisation. Definicje finansyzacji akcentuja na ogół szczególną i rosnąca rolę sfery finansowej oraz kryteriów finansowych w funkcjonowaniu życia ekonomicznego i społecznego. W wąskim znaczeniu finansyzacja kojarzona jest przede wszystkim z rosnącym znaczeniem działalności finansowej w aktywności podmiotów ekonomicznych o charakterze niefinansowym. Konsekwencja tego jest zmiana strumieni dochodów, w których coraz większy udział maja dochody czerpane właśnie z działalności finansowej, a nie z tradycyjnie rozumianej działalności operacyjnej i inwestycyjnej ${ }^{5}$.

są z tego punktu widzenia niczym szczególnym. Wystarczy wspomnieć tekst Josepha Schumpetera odnaleziony już po jego śmierci (The „Crisis” in Economics: Fifty Years Ago, „Journal of Economic Literature” 20, 1982 (September); artykuł Joan Robinson, The Second Crisis of Economic Theory, „American Economic Review” 62, 1972, nr 1-2, czy wreszcie zbiorowe opracowanie The Crisis in Economic Theory (red. D. Bell, I. Kristol, Basic Books Inc. Publishers, New York 1981) zawierające m.in. bardzo interesujący esej Petera Druckera. Tytuł tego eseju Towards the Next Economics został wykorzystany jako tytuł całego zbioru prac Druckera wznowionych w $2010 \mathrm{r}$.

${ }^{3}$ Charakterystyczna dla ekonomicznego triumfalizmu jest wypowiedź przypisywana jednemu z laureatów Nagrody Nobla z ekonomii Georgowi Stiglerowi, który odpowiadając na pytanie, dlaczego nie ma nagród noblowskich z innych obszarów nauk społecznych, miał powiedzieć: „Nie martwcie się o nich, przecież moją Nobla w literaturze" (cyt. za: Ł. Goczek, Ekspansja teorii ekonomii, w: A. P. Balcerzak, D. Górecka (red.), Dylematy teorii ekonomii w rzeczywistości gospodarczej XXI wieku, Wyd. A. Marszałek, Toruń 2007.

${ }^{4}$ Ten fragment opracowania oparty jest na M. Ratajczak, Finansyzacja gospodarki, „Ekonomista" 2012, nr 3, s. 281-302.

${ }^{5}$ Ö. Orhangazi, Finacialization and the US Economy, Edward Elgar, Northampton, MA, 2008; A. Ząbkowicz, Wzrost znaczenia dochodów z operacji finansowych w korporacjach nie-finansowych (financialization) - kontekst instytucjonalny, „Organizacja i Kierowanie” 2009, nr 2. 
W szerokim znaczeniu finansyzacja to proces autonomizacji sfery finansowej w relacji do sfery realnej, a nawet uzyskiwania nadrzędności tej pierwszej w stosunku do drugiej. W ramach finansyzacji rynki finansowe oraz elity finansowe uzyskuja coraz większy wpływ na politykę ekonomiczną oraz na efekty gospodarowania ${ }^{6}$. Dla części badaczy finansyzacja jest świadectwem nowego stadium kapitalizmu określanego mianem kapitalizmu finansowego, kapitalizmu rentierskiego, bankokracji czy też kapitalizmu „odcinania kuponów”. W nawiązaniu do tradycji Keynesowskiej niekiedy pisze się też o kapitalizmie kasynowym. Wreszcie autorzy najbardziej radykalnych koncepcji uważają, że finansyzacja jest wręcz zwiastunem ,jesieni” kapitalizmu (co nie znaczy, że gospodarki rynkowej) oraz kształtowania się kompleksu finansowo-politycznego, który swoimi wpływami i znaczeniem przekracza rolę dawnego kompleksu militarno-przemysłowego ${ }^{8}$. Ekonomiści nawiązujący do tradycji marksowskiej skłonni są z kolei pisać o monopolistyczno-finansowym stadium gospodarki kapitalistycznej ${ }^{9}$. Finansyzacja ma być także jednym z przejawów przechodzenia od demokracji do plutokracji, czyli rządów pieniądza i jego dysponentów.

Finansyzacja prowadzi do zasadniczych zmian w sferze zarządzania i własności, zwłaszcza dużych przedsiębiorstw. W obszarze własności wiąże się to z coraz większą rola właścicieli instytucjonalnych ze sfery finansowej, którzy kojarzeni sa z tak zwanym kapitałem niecierpliwym, szukającym możliwości uzyskania nadzwyczajnych zysków w krótkim okresie ${ }^{10}$. Zdaniem krytyków zmian, które pod wpływem narastającej finansyzacji dokonują się na poziomie przedsiębiorstw - szczególnie wiele złego dokonało upowszechnienie się idei wartości dla akcjonariuszy (shareholder value) związane z przesuwaniem akcentów w dyskusji o zarządzaniu z perspektywy interesariuszy (stakeholder perspective) na perspektywe udziałowców, akcjonariuszy (shareholder perspective $)^{11}$. W połączeniu $\mathrm{z}$ narastająca tendencją do skracania horyzontu czasowego podejmowanych decyzji inwestycyjnych doprowadziło to do nadmiernego wyeksponowania $\mathrm{w}$ analizie ekonomiczno-finansowej całej grupy wskaźników uwzględniających przede wszystkim krótkookresową zyskowność, a nie długookresową stabilność rozwoju danego przedsięwzięcia ${ }^{12}$.

Krytycy idei finansyzacji, a zwłaszcza traktowania będących jej wyrazem zjawisk jako świadectwa jakiejś istotnej, fundamentalnej zmiany współczes-

${ }^{6}$ G. A. Epstein (red.), Financialisation and the World Economy, Edward Elgar Pub, 2006; E. Stockhammer, Finacialisation and the Slowdown of Accumulation, „Cambridge Journal of Economics” 28, 2004, nr 5; R. Boyer, Is a Finance-Led Growth Regime a Viable Alternative to Fordism? A Preliminary Analysis, „Economy and Society” 29, 2000, nr 1.

${ }^{7}$ J. Froud, C. Haslam, S. Johal, K. Williams, Financialisation and the Coupon Pool, „Gestão \& produção" 8, 2001, nr 3 .

${ }^{8}$ R. B. Freeman, It's Financialization!, „International Labour Review” 149, 2010, nr 2; E. Maczyńska, Czy to starość?, „Gazeta Bankowa” z 7 kwietnia 2009 r.

9 J. B. Foster, The Financialization of Capitalizm, „Monthly Review” 58, 2007, nr 11; G. Isaacs, Contemporary Financialization: A Marxian Analysis, „Journal of Political Inquiry” 2011, nr 4.

${ }_{10}$ P. Rossman, G. Greenfield, Finacialisation, „Education ouvrière” 2006, nr 1.

${ }_{11}$ T. I. Palley, The Macroeconomics of Financialization: A Stages of Development Approach, „Ekonomiaz” 2009, N. ${ }^{\circ}$ 72, 3.er cuatrimestre.

12 J. Froud, C. Haslam, S. Johal, K. Williams, op. cit.; K. Williams, From Shareholder Value to Present-Day Capitalism, „Economy and Society” 29, 2000, nr 1. 
nej gospodarki rynkowej, traktują to wszystko, co składa się na finansyzację, jako przejawy pewnych naturalnych przeobrażeń niedających podstaw do istotnej rewizji paradygmatów oraz konstrukcji teoretycznych i modelowych. Ponieważ w modelu neoklasycznym i jego pochodnych zakłócenia w działaniu rynku mogą mieć w zasadzie tylko charakter egzogeniczny, nie dziwi więc, że wspomniana grupa ekonomistów szuka przyczyn ostatniego kryzysu przede wszystkim w psujących rynek działaniach państwa.

W przekonaniu autora opracowania finansyzacja nie jest zapowiedzia upadku kapitalizmu, ale też trudno ją traktować jako zjawisko marginalne czy przejściowe. Finansyzacja jest wyrazem pewnych procesów historycznych o charakterze obiektywnym, a jej nasilanie się od zarania dziejów jest niejako wpisane $\mathrm{w}$ historię ludzkości związaną z niezwykłą innowacją ekonomiczna i społeczna, jaka jest pieniądz. Nieprzypadkowo już Arystoteles rozróżniał ekonomię i chrematystykę, tę pierwszą utożsamiając z powiększaniem bogactwa droga działań społecznie użytecznych i związanych głównie z funkcjonowaniem sfery realnej, a tę druga - z traktowaniem bogactwa jako celu samego w sobie i jego pomnażaniem droga spekulacji finansowych. Kolejne innowacje w sferze finansów i pieniądza niewątpliwie przyczyniały się i przyczyniaja do rozwoju gospodarki i społeczeństwa, ale zarazem kreują różnego rodzaju zagrożenia związane z autonomizacja pieniądza w stosunku do zjawisk ze sfery realnej. Gospodarka towarowo-pieniężna, w której pieniądz jest traktowany jako przede wszystkim pośrednik w wymianie jednych dóbr na inne, w praktyce staje się często pieniężno-towarowa, w której towar jest tylko pośrednim ogniwem przejścia od mniejszych do większych zasobów pieniądza, a nawet pieniężno-pieniężna, w której pieniądz w całkowitym oderwaniu od sfery realnej kreuje kolejne strumienie pieniężne.

Niewątpliwie finansyzacja stanowi istotny impuls do dyskusji o ewentualnych zmianach w ekonomii jako nauce.

\section{KRYZYS EKONOMII CZY EKONOMIA W DOBIE KRYZYSU? ${ }^{13}$}

Nasilona wraz z ostatnim kryzysem dyskusja na temat kondycji współczesnej ekonomii, zwłaszcza w swym wymiarze publicystycznym, charakteryzuje się, jak już wspominano, znaczną polaryzacją stanowisk, a zarazem niekiedy dość emocjonalnym tonem. Odrzucając zarówno antyekonomizm, jak i ekonomiczny triumfalizm, warto jednak zastanowić się nad tym, czy i jakie zmiany powinny nastapić $\mathrm{w}$ ekonomii w celu poprawy jej zdolności zarówno eksplanacyjnych, jak i predykcyjnych. Przy tym w przekonaniu autora współczesna ekonomia ani nie jest tak zła, jak twierdzą ci, którzy podnosza chociażby kwestię nieprzewidzenia przez większość ekonomistów ostatniego kryzysu, ani tak znakomita, jak uważają ci, którzy nie widzą potrzeby istotnych zmian w tym obszarze nauki i co najwyżej skłonni są dyskutować o zróż-

${ }_{13}$ Ten, jak i kolejny fragment opracowania oparto na M. Ratajczak, Co dalej z ekonomia?, w: M. Bochenek (red.), Szkice z historii ekonomii, PTE Oddział w Toruniu, Toruń 2011, s. 195-214. 
nicowanych kompetencjach samych ekonomistów ${ }^{14}$. Rzeczywistość ekonomii jako nauki jest odzwierciedleniem wszystkich problemów, które są typowe dla nauk społecznych. Tyle tylko, że część ekonomistów, zwłaszcza związanych ze współczesną ekonomia głównego nurtu, prezentowała i prezentuje dokonania ekonomii w taki sposób, jakby była ona częścią nauk ścisłych, od których oczekuje się znacznie większej precyzji i zdolności predykcyjnych, niż to ma miejsce w wypadku nauk społecznych. Można to ując inaczej, że ekonomia i ekonomiści padaja raz po raz ofiara przypisywania sobie swoistego szlachectwa w ramach nauk społecznych, a jak wiadomo noblesse oblige (szlachectwo zobowiązuje). Skoro stopień formalizacji niektórych tekstów ekonomicznych jest porównywalny $\mathrm{z}$ opracowaniami z nauk ścisłych, a nawet nauk formalnych, takich jak matematyka, to trzeba być przygotowanym na to, że zwiększa to oczekiwania dotyczace precyzji i konkretności odpowiedzi na pytania dotyczące istoty otaczającej nas rzeczywistości gospodarczej, a także - a nawet przede wszystkim - związane z predykcja.

Na pytanie, czy ekonomia jako nauka znajduje się w kryzysie, zdaniem autora możliwa jest dwojaka odpowiedź. Ekonomia nie jest w kryzysie w takim rozumieniu, jakie charakterystyczne jest zwłaszcza dla ocen dorobku ekonomii głównego nurtu dokonywanych przez radykalnych przedstawicieli współczesnego antyekonomizmu. Nie jest uzasadnione twierdzenie, że ekonomia nie ma trwałych i praktycznie użytecznych osiagnięć i że zarówno w sferze mikroekonomicznej, jak i szczególnie nas interesującej w prezentowanym opracowaniu - sferze makroekonomicznej pozostaje wyłącznie zdać się albo na doświadczenie i umiejętności uczestników życia gospodarczego, albo na swoisty szczęśliwy (lub nie) zbieg okoliczności. Wystarczy porównać, oczywiście zachowując świadomość wszystkich różnic historycznych, Wielki Kryzys przełomu lat dwudziestych i trzydziestych XX w. i towarzyszace mu reakcje i działania poszczególnych państw z obecnym kryzysem, aby dostrzec istotne i to pozytywne różnice, które zwłaszcza w sferze zastosowanych instrumentów polityki makroekonomicznej w znacznej mierze są pochodną rozwoju ekonomii jako nauki.

Całkowicie bezzasadne jest także twierdzenie, że ekonomia nie jest nauka. Oczywiście ekonomia nie jest i nigdy nie będzie nauką ścisła, choć oczywiście w pewnych swych obszarach może odwoływać się do standardów charakterystycznych dla nauk ścisłych czy nauk formalnych. Ekonomia matematyczna, ekonometria, statystyka, czyli najbardziej zmatematyzowane obszary ekonomii, pozwalają na znacznie większy stopień formalizacji i ścisłości niż te wszystkie składniki ekonomii, które bliższe są analizie zjawisk gospodarczych w ich w pełni społeczno-jakościowym wymiarze.

Nie uzasadniają także twierdzenia o kryzysie w ekonomii ograniczone możliwości predykcji. Choć oczywiście ideałem, acz nie osiagalnym, byłaby daleko idąca czy wręcz pełna zdolność przewidywania przebiegu zjawisk gospodarczych, to musimy zaakceptować, że co prawda, doskonaląc narzędzia badawcze, możemy nasze możliwości predykcyjne zwiększać, ale naturalna zmienność zjawisk gospodarczych i ich ścisłe związki z innymi obszarami ży-

${ }^{14}$ T. Żylicz, Komu przyda się rewolucja, „Rzeczpospolita” z 8 stycznia 2009 r. 
cia społecznego powodować będa, że nasze coraz lepsze narzędzia poznania i zrozumienia rzeczywistości ekonomicznej będą mieć i tak ograniczoną zdolność eksplanacyjną i prognostyczną. Musimy się więc liczyć z tym, że teorie czy koncepcje ekonomiczne i budowane na ich podstawie narzędzia analizy i prognozowania rzeczywistości gospodarczej nie mają bezwzględnego, w wymiarze czasowo-przestrzennym, waloru uniwersalizmu. Musimy się także liczyć z tym, że zjawiska występujące w rzeczywistości gospodarczej będą tłumaczone i opisywane za pomocą różnych koncepcji i narzędzi, a wyciagane na tej podstawie wnioski, także te o charakterze predykcyjnym, będą niekiedy mocno zróżnicowane.

Do tej pory zaprezentowano elementy odpowiedzi przeczacej na pytania o kryzys w ekonomii. Ale, jak już sygnalizowano, na to pytanie możliwa jest także odpowiedź twierdząca. Taka odpowiedź jest możliwa, jeśli odwołamy się do teorii rewolucji naukowych. Zgodnie z tą koncepcja w rozwoju nauki można wydzielić okresy normalnego rozwoju, kiedy to badania prowadzone sa zgodnie z obowiązującym, czy też dominującym, paradygmatem, oraz okresy rewolucyjnych zmian, kiedy to sytuacje kryzysowe związane $\mathrm{z}$ narastaniem wątpliwości co do dominujaccego paradygmatu prowadzą do nasilania się prób jego podważenia i odrzucenia. Nie ma przy tym gwarancji, że nowy czy też alternatywny paradygmat musi być bezwzględnie lepszy od poprzedniego. Ponieważ o zmianach paradygmatu decyduje wola większości badaczy, może się okazać, że kształtujący się konsens teoretyczno-metodologiczny będzie oznaczał przyjęcie koncepcji niestanowiących rzeczywistego postępu w stosunku do koncepcji odrzuconych czy spychanych $\mathrm{z}$ piedestału idei dominujacych. Paul Krugman uważa, że jednym z istotnych problemów współczesnej ekonomii był właśnie, określany przez niego mianem fałszywego, konsens w makroekonomii towarzyszacy temu, co popularnie określane jest mianem rewolucji, czy kontrrewolucji neoliberalnej ${ }^{15}$.

Obserwując, co dzieje się aktualnie w ekonomii, można niewątpliwie dostrzec oznaki kryzysu w rozumieniu teorii rewolucji naukowych. Wyraźne jest zwątpienie w przydatność części koncepcji i narzędzi rozwiniętych zwłaszcza w ramach ekonomii głównego nurtu w jej obszarze kojarzonym z tradycja neoklasyczną. Na nowo popularne stało się odwoływanie do tradycji keynesowskiej i znacznie bardziej aktywni stali się przedstawiciele różnych mniej lub bardziej radykalnych odłamów poza-keynesowskiej myśli heterodoksyjnej. Zwłaszcza przedstawiciele różnych składowych ekonomii instytucjonalnej czy ewolucyjnej poddają niekiedy radykalnej krytyce ekonomię głównego nurtu. Tyle tylko, że o ile właśnie w sferze krytyki ekonomii głównego nurtu, zwłaszcza w jej zasadniczej części nawiązującej do tradycji neoklasycznej, przedstawiciele radykalnej myśli heterodoksyjnej sa nierzadko przekonujacy, o tyle znacznie trudniej przychodzi im zaproponowanie programu badawczego, który byłby na tyle spójny i możliwy do wykorzystania, aby mógł pretendować do miana realnego rywala ekonomicznej ortodoksji.

15 P. Krugman, How Did Economists Get It So Wrong?, „The New York Times” 2009, September 6. 


\section{POŻĄDANE ZMIANY W EKONOMII}

Odrzucenie twierdzenia o kryzysie ekonomii w rozumieniu takiego nagromadzenia przykładów jej rozmijania się z realiami życia gospodarczego, że uzasadniałoby to zakwestionowanie prawie całego jej dotychczasowego, dorobku, nie jest tożsame z uznaniem, że nie są potrzebne, i to niekiedy istotne, zmiany. Po pierwsze: podkreślić należy konieczność akceptacji zmienności świata ekonomicznego i ewolucyjnego charakteru zjawisk gospodarczych. Przy tym w odniesieniu do ewolucyjności należy zwrócić uwagę, że nie chodzi o ewolucyjność w rozumieniu naturalistycznym, typowym dla świata przyrody i którą dostrzegał i rozumiał już Adam Smith, ale o ewolucyjność o charakterze kulturowym. Oczywiście w punkcie wyjścia analiz ekonomicznych i będących na bardzo wysokim poziomie abstrakcji modelach można od idei ewolucyjności odstępować, ale powinno to być traktowane jako swoiste założenie idealizujące, a nie fundament analizy ekonomicznej.

Po drugie: idea ewolucji musi się wiązać z szerszym uwzględnieniem historycznego wymiaru zjawisk ekonomicznych i samej ekonomii. W tym kontekście należy zauważyć tendencję, widoczną chociażby na poziomie większości programów nauczania ekonomii, do ograniczania czy wręcz eliminowania takich przedmiotów, jak historia gospodarcza czy historia myśli ekonomicznej. Już na tym etapie kształtowania zarówno przyszłych praktyków, jak i badaczy gospodarki ginie czy też ulega poważnemu ograniczeniu świadomość zjawisk gospodarczych jako zjawisk historycznych, nierzadko kumulacyjnych i ewolucyjnych, czy powtarzających się, acz w zmienionych warunkach. Brak świadomości historycznej zjawisk gospodarczych, tudzież ich związków z innymi zjawiskami społecznymi, powoduje, że skraca się perspektywa myślenia o ekonomii do tu i teraz. Brak świadomości historycznego, a zarazem głównie ewolucyjnego, a nie rewolucyjnego rozwoju ekonomii utrudnia właściwą ocenę tego, gdzie są istotne luki w gmachu wiedzy ekonomicznej wymagające wypełnienia, a gdzie - w zasadzie poza ćwiczeniem intelektu - niewiele jesteśmy w stanie osiagnacć.

Po trzecie: uznaniu ewolucyjnego charakteru zjawisk ekonomicznych w ich wymiarze kulturowym powinno towarzyszyć bardziej niż do tej pory rzeczywiste, a nie deklaratywne uznanie, że „instytucje mają znaczenie”. Oczywiście przesadą byłoby twierdzenie, że ekonomia instytucjonalna miałaby stać się swoistą nową ortodoksja. Chodzi jednak o uznanie, że instytucje są ważne nie tylko jako istotny element analizy zjawisk ekonomicznych na poziomie badań empirycznych i faktografii, lecz także muszą być uwzględniane jako integralny element fundamentów metodologicznych badań ekonomicznych także w ich wymiarze teoretycznym.

Po czwarte: ekonomia powinna przejść od imperializmu do idei kooperacji i wzajemnego wzbogacania się z innymi naukami społecznymi. Tak jak elementy analizy ekonomicznej trafiły do np. socjologii, tak również ekonomia musi być otwarta na czerpanie $\mathrm{z}$ dorobku innych nauk społecznych. Nieprzypadkowo w zasadzie od nowożytnych początków ekonomii jako nauki do czasów opublikowania przez Alfreda Marshalla Zasad ekonomiki większość 
fundamentalnych prac miała w tytule określenie ekonomia polityczna, czyli właśnie ekonomia społeczna. Dla Smitha tak samo ważny był mechanizm, który zaprezentował w Badaniach nad naturq $i$ przyczynami bogactwa narodów, zgodnie z którym szczególną rolę w naszym zachowaniu w sferze ekonomicznej odgrywa żądza zysku, jak i obraz człowieka z wcześniejszej Teorii uczuć moralnych. W pewnym uproszczeniu ideę Smitha wynikająca z porównania obu dzieł można sprowadzić do przekonania, że choć w sferze zachowań ekonomicznych szczególnie istotny jest motyw zysku, to nie oznacza to, że w tym obszarze aktywności ludzie nie powinni kierować się zasadami etyki i moralności oraz tym, co Smith określał mianem sympatii, a co dziś raczej kojarzy się z ideą empatii. Oczywiście niebezpieczeństwem, które wiąże się z szerokim odwoływaniem się w ekonomii do innych nauk społecznych, jest ryzyko zacierania się granicy między rygoryzmem badań naukowych a uprawianiem swoistej publicystyki ekonomicznej pod szyldem socjoekonomii, politoekonomii czy psychoekonomii. W kontekście dyskusji o związkach ekonomii z innymi naukami społecznymi warto zauważyć, że zdaniem Davida Colandera w przyszłości podziały między ekonomia a innymi naukami społecznymi będa znacznie mniej ostre i że na miejsce dzisiejszych ekonomistów, socjologów pojawią się po prostu specjaliśsi od nauk społecznych mający kompetencje z tych dziś odmiennych dyscyplin nauki ${ }^{16}$.

Po piąte: wszystkie wymienione do tej pory oczekiwane czy postulowane zmiany w ekonomii musiałyby się także wiązać z odejściem od tradycyjnie rozumianej idei homo oeconomicus. Ani ewolucyjne spojrzenie na życie ekonomiczne, ani szersze odwołanie się do idei instytucji zarówno w kategoriach ich wpływu na zachowanie ludzi (to eksponuje tradycyjny instytucjonalizm), jak i w rozumieniu kształtowania się instytucji pod wpływem czy jako efektu zachowań ludzi (to istotny element założeń nowej ekonomii instytucjonalnej), ani uwzględnianie w analizie ekonomicznej pozaekonomicznych motywów zachowań ludzi nie są możliwe na gruncie ortodoksyjne wizji człowieka, który w sferze ekonomicznej rozumuje wyłącznie w kategoriach stosukowo prostego wymiaru kosztów i korzyści, a na dodatek zachowuje się w pełni racjonalnie i działa niezależnie od innych ludzi. Oczywiście nie wydaje się zasadne sprowdzanie analizowanej zmiany do prostego zastapienia homo oeconomicus przez homo sociologicus. Raczej chodzi o uwzględnienie, że homo sapiens jest - także w sferze ekonomicznej - homo compositus, acz w znaczeniu „złożony”, „,skomplikowany”, a nie - także możliwym do przetłumaczenia - „wymyślony”.

Po szóste: pożądane jest pewne przewartościowanie poglądów na rolę matematyki w ekonomii. W zasadzie od końca XIX w. istotna część ekonomistów podejmowała i podejmuje próby uczynienia z ekonomii najbardziej ścisłej spośród nauk nieścisłych (inexact science w ujęciu Johna Stuarta Milla). Wiąże się to w znacznej mierze z szerokim zastosowaniem matematyki. Doceniając będące tego rezultatem osiagnięcia naukowe, należy jednak zauważyć, że problemów ekonomicznych nie da się sprowadzić ani do zbioru aksjomatów, ani zagadek matematycznych. Nadmierne eksponowanie techniczno-matema-

${ }^{16}$ D. Colander, The Complexity Revolution and the Future of Economics, „Middlebury College Working Paper Series” 2003, nr 0319. 
tycznego wymiaru ekonomii i zarządzania powoduje, że także w praktyce, chociażby w sektorze finansowym, rodzi się czy - jak pokazuja ostatnie wydarzenia - wręcz narodziła się swoista pokusa postrzegania rozwiązań formalnych (nowe, złożone od strony techniczno-matematycznej produkty) jako swoistego panaceum na tradycyjne problemy, a zwłaszcza te związane z pojęciem ryzyka podejmowanych decyzji. Przewartościowania poglądów na rolę matematyki w ekonomii nie należy jednak utożsamiać z ideą ograniczania zastosowania matematyki, ale wręcz z wzrostem jej wykorzystania. Matematyka na usługach ekonomii powinna być wykorzystywana do coraz szerszego testowania koncepcji teoretycznych ${ }^{17}$. Natomiast zmniejszeniu powinny ulec oczekiwania co do roli matematyki jako swoistego kamienia filozoficznego pozwalającego na uczynienie z ekonomii nauki zbliżonej do nauk ścisłych. Przy okazji warto zauważyć, że większość z dzieł stanowiących kamienie milowe w rozwoju ekonomii to prace charakteryzujące się stosunkowo ograniczonym wykorzystaniem matematyki i aparatu matematycznego ${ }^{18}$.

Po siódme: niezbędne wydaje się także nowe spojrzenie na rolę państwa w gospodarce i odejście od dychotomii: albo traktowania państwa jako prawie że zła koniecznego, którego obecność w gospodarce można uzasadnić w zasadzie tylko zawodnością rynku, a w tym sferą dóbr publicznych, albo prezentowania państwa jako substytutu rynku i instytucji omnipotentnej. W obecnych realiach ekonomicznych nie wydaje się zasadne analizowanie rynku i państwa w kategoriach alternatywy. W gospodarce, która stanowi jeden z podsystemów całego życia społecznego, potrzebny jest rynek jako mechanizm podstawowy z punktu widzenia zapewnienia mikroekonomicznej efektywności. Potrzebne jest jednak także państwo jako instytucja regulująca oraz chroniąca przed nadużywaniem władzy ekonomicznej do realizacji partykularnych interesów. Rynek wolny to nie to samo co rynek nieregulowany ${ }^{19}$.

Po ósme: ekonomia powinna stać się bardziej pluralistyczna w rozumieniu akceptacji różnych teorii i koncepcji nawiązujących do niekiedy odmiennych paradygmatów. Zresztą coraz częściej, pomijając najbardziej zagorzałych zwolenników czystości podejścia w kategoriach konkretnej szkoły czy teorii, ekonomiści uprawiają ekonomię eklektyczną czy też tzw. ekonomię złożoności ${ }^{20}$. Oczywiście, podobnie jak w wypadku dyskutowanego wcześniej łączenia eko-

17 B. Czarny, Metodologiczne osobliwości ekonomii, „Bank i Kredyt” 2007, nr 7.

18 Sceptycznie do matematyzacji ekonomii odnosiło się wiele postaci. Wystarczy wspomnieć słowa Miltona Friedmana, że „ekonomia coraz bardziej staje się tajemną gałęzią matematyki, zamiast zajmować się rzeczywistymi problemami gospodarczymi” (cyt. za: B. Snowdon, H. R. Vane, Rozmowy z wybitnymi ekonomistami, Polskie Towarzystwo Ekonomiczne, Warszawa 2003, s. 189). Alfred Marshall, będąc wielkim zwolennikiem korzystania z matematyki w ekonomii, dostrzegał zarazem niebezpieczeństwo polegające na uleganiu pokusie stosowania coraz bardziej wyrafinowanych narzędzi, a zarazem oddalaniu się od realiów gospodarczych. Jak pisał: „Prawdziwą kwestią nie jest to, czy zastosowanie rozumowania matematycznego do nauk moralnych [ekonomia była zaliczana do tej grupy - przyp. M.R.] jest możliwe, ale czy jest ono korzystne", cyt. za: J. Dzionek-Kozłowska, System ekonomiczno-społeczny Alfreda Marshalla, WN PWN, Warszawa 2007, s. 77.

19 D. Acemoglu, The Crisis of 2008: Structural Lessons for and from Economics, http://econwww.mit.edu/files/3703.

${ }^{20}$ A. Wojtyna, op. cit. 
nomii z innymi naukami, eklektyzm czy złożoność nie mogą być synonimem swoistego miszmaszu ekonomicznego.

Po dziewiąte: ekonomiści, mając słuszne powody do satysfakcji z rozwoju swojej nauki na przestrzeni ostatnich ponad dwustu lat, czyli od momentu opublikowania Badań nad natura $i$ przyczynami bogactwa narodów przez Smitha, powinni jednak zarazem zaakceptować, że ekonomia, będąc nauka społeczna, nigdy nie będzie mogła aspirować do bycia nauką quasi-ścisła. Bez względu na wyrafinowanie i techniczną złożoność narzędzi analizy zawsze będziemy mieć problem z predykcją i zawsze będziemy narażeni na zarzuty, że czegoś nie przewidzieliśmy bądź źle przewidzieliśmy. Pewna doza pokory wobec złożoności świata, który staramy się poznać i zrozumieć, jest czymś absolutnie niezbędnym.

\section{ZAKOŃCZENIE}

Innowacje $\mathrm{w}$ nauce, a w tym w ekonomii, związane z kryzysem w rozumieniu teorii rewolucji naukowych nie muszą oznaczać przyjmowania koncepcji bezwzględnie lepszych od wcześniej dominujących. Choć autorzy prac naukowych z ekonomii dość często odwołują się do falsyfikacjonizmu, którego zastosowanie miałoby pozwolić na zakwestionowanie jakiegoś ze składników teorii lub utrwalić przekonanie o jego słuszności, to w rzeczywistości znacznie częściej realizują konfirmacjonizm mniej lub bardziej skażony zasadą pars pro toto.

Koncepcja finansyzacji, właśnie w celu uniknięcia zarzutu, że przez dobór faktów wygodnych z punktu widzenia jej zwolenników nadaje się jej wymiar zjawiska o fundamentalnym znaczeniu, wymaga dalszych studiów i badań prowadzących do prób konstrukcji bardziej niż do tej pory dojrzałych modeli czy teorii, a następnie ich testowania. Jak na razie takich prób jest stosunkowo mało ${ }^{21}$. Nawet jednak już na obecnym etapie analiz zasadne wydaje się uznanie, że finansyzacja i jej konsekwencje powinny być uwzględniane w badaniach naukowych jako jeden z elementów szerszych zmian we współczesnej ekonomii.

Nie ulega wątpliwości, że ekonomia musi się zmieniać wraz ze zmianami będącego przedmiotem jej zainteresowań świata, i to nie tylko w jego gospodarczym wymiarze. Jednakże w dyskusjach na temat teraźniejszości i przyszłości ekonomii należy unikać stanowisk skrajnych. Nie akceptując antyekonomizmu, nie powinnyśmy także ulegać ekonomicznemu triumfalizmowi i związanemu z tym prezentowaniu poszczególnych teorii, czy koncepcji w kategoriach ostatecznego wyjaśnienia mechanizmów rządzących rozwojem świata w sferze gospodarczej. Musimy zaakceptować, na co już zwracano uwagę, ewolucyjność życia ekonomicznego nie w rozumieniu zmian determinowanych

${ }^{21}$ R. Boyer, op. cit.; E. Stockhammer, op. cit.; T. van Treeck, A Synthetic, Stock-Flow Consistent Macroeconomic Model of “Financialisation”, „Cambridge Journal of Economics” 33, 2009, nr 3 . 
prawami natury funkcjonującymi niezależnie od ludzi, a w rozumieniu przeobrażeń dokonujących się w rzeczywistości społecznej, także w obszarze kulturowym. Tak rozumiany ewolucjonizm nie pozwala na postrzeganie zmian w świecie ekonomicznym jako opartych na ideach uniformizmu, liniowości czy progresywizmu, a tym bardziej finalizmu. Nie ma i nie będzie końca historii także w sferze zjawisk ekonomicznych, a co za tym idzie - nie ma i nie będzie końca przeobrażeń ekonomii jako nauki. Nawet najbardziej zaawansowane w kategoriach formalnych narzędzia poznania świata realnego nie sa w stanie uchronić nas przed występowaniem zjawisk i zdarzeń, które tylko w ograniczonym stopniu jesteśmy w stanie przewidzieć. Milton Friedman powiedział, że „to co sprawia, że jest ona [ekonomia - M. R.] najbardziej fascynujacca, jest to, że jej fundamentalne zasady są tak proste, że każdy jest w stanie je zrozumieć, jednak niewielu je rozumie"22. Być może sprawa jest jeszcze bardziej złożona i musimy pogodzić się z tym, że do końca nie zrozumiemy tych zasad nigdy, co nie znaczy, że nie możemy, doskonaląc ekonomię, zwiększać, i to istotnie, nasze zdolności eksplanacyjne i predykcyjne.

Na zakończenie wróćmy do pytania o to, czy i w jakim stopniu to ekonomiści i uprawiana przez nich nauka moga być postrzegani jako odpowiedzialni za ostatni kryzys. Niewątpliwie, o czym już pisano, część ekonomistów uległa (m.in. pod wpływem upadku systemu gospodarki centralnie zarządzanej, a zarazem relatywnie długiego okresu dobrej koniunktury w wielu gospodarkach rynkowych) złudzeniu, że nastapił swoisty koniec historii i że udało się w sposób wyczerpujący i ostateczny wytłumaczyć mechanizmy rządzące współczesną rzeczywistością gospodarczą. Na przełomie XX i XXI w. byli ekonomiści, którzy m.in. zastanawiali się, czy warto nadal dyskutować o zjawisku cykliczności w funkcjonowaniu gospodarki rynkowej i możliwości wystapienia kryzysu. Tak zwana nowa ekonomia, w sferze realnej kojarzona z rozwojem szeroko rozumianej elektronizacji i informatyzacji, miała wiązać się z radykalnym przeobrażeniem tradycyjnych mechanizmów funkcjonowania gospodarki rynkowej. Efektywne rynki i racjonalne oczekiwania podmiotów gospodarczych miały z jednej strony wykluczać potrzebę i sens interwencji państwa, a z drugiej - chronić przed pojawianiem się turbulencji ekonomicznych innych niż przejściowe i raczej marginalne zakłócenia we wzroście i rozwoju. Dziś z perspektywy ostatnich lat i wspominanego na początku opracowania ostatniego kryzysu wiemy, że świat realny okazał się - jak zwykle zreszta - bardzo nieidealny i że nowa ekonomia to bardziej kwestia zmiany form niż treści zjawisk gospodarczych.

Uznanie, że ekonomiści powinni zastanowić się nad przyszłością swojej nauki i niezbędnymi zmianami, nie jest tożsame z akceptacją tezy, że to ekonomiści i ich nauka sa głównymi odpowiedzialnymi za ostatni kryzys. Ekonomia jako nauka i jej ustalenia są bowiem przede wszystkim narzędziami, które mogą być lepiej lub gorzej wykorzystywane przez tych wszystkich, którzy zarówno w skali mikroekonomicznej, jak i w skali makroekonomicznej podejmują decyzje gospodarcze. Jak zauważył już w XIX w. Nassau Wiliam Senior,

${ }^{22}$ Zob. http://miltonfriedman.pl/cytaty.html (dostęp: 7.04.2014). 
między ekonomią jako nauką a stosowaniem ustaleń ekonomii w praktyce gospodarczej jest podobna różnica jak między nawigacja, wykorzystująca wiedzę m.in. astronomiczna, jako nauką o regułach żeglowania a umiejętnościa zastosowania tych reguł przez konkretnych żeglarzy w celu szczęśliwego doprowadzenia okrętu do portu docelowego. Oczywiście nie zwalnia to badaczy studiujących reguły nawigacji z konieczności stałego pogłębiania swojej wiedzy i doskonalenia swojej nauki. Ekonomia, jako nauka dostarczająca wiedzy o tym, jak żeglować po morzach i oceanach współczesnej gospodarki, także musi być stale rozwijana i doskonalona.

prof. dr hab. Marek Ratajczak

Uniwersytet Ekonomiczny w Poznaniu

oraz Sekretarz Stanu w Ministerstwie Nauki i Szkolnictwa Wyższego

m.ratajczak@ue.poznan.pl

\section{ECONOMICS IN THE AGE OF 'FINANCISATION' OF ECONOMY}

Sum mary

Towards the end of the first decade of the twenty first century, when the first symptoms of a crisis in the world economy appeared, the discussion on the condition of economic sciences became more lively. The author presents his view of the necessary changes in economy, which account, among others, for its 'financisation.' Economics as a social science must undergo constant transformations along with the changes occurring in the subject of its interest. Even the most advanced (in formal categories) tools enabling cognition of the real world cannot fully ensure effective prediction in the economic sphere. Notwithstanding the above, the scientific status of economy should not be undermined. 
Copyright of Journal of Law, Economics and Sociology is the property of Faculty of Law and Administration of Adam Mickiewicz University in Poznan and its content may not be copied or emailed to multiple sites or posted to a listserv without the copyright holder's express written permission. However, users may print, download, or email articles for individual use.

Właścicielem praw autorskich do „Ruchu Prawniczego, Ekonomicznego i Socjologicznego” jest Wydział Prawa i Administracji Uniwersytetu im. Adama Mickiewicza w Poznaniu. Zawartość czasopisma nie może być kopiowana, przesyłana do innych stron internetowych bądź zamieszczana na blogach bez pisemnej zgody wydawcy. Niemniej artykuły można drukować, kopiować lub przesyłać w formie elektronicznej na własny użytek. 